\title{
Effect of carbon starvation and proteolytic activity on stationary-phase acid tolerance of Streptococcus mutans
}

\author{
G. Svensäter, ${ }^{1}$ Olof Björnsson ${ }^{1}$ and I. R. Hamilton ${ }^{2}$ \\ Author for correspondence: I. R. Hamilton. Tel: +1 204789 3615. Fax: +1 2047893948. \\ e-mail:ihamilt@cc.umanitoba.ca
}

1 Department of Oral Biology, Centre for Oral Health Sciences, Malmö University, Malmö, Sweden

2 Department of Oral Biology, Faculty of Dentistry, University of Manitoba, 780 Bannatyne Ave, Winnipeg, Manitoba, Canada R3E OW2

\begin{abstract}
Previous research with Streptococcus mutans and other oral streptococci has demonstrated that the acid shock of exponential-phase cells (pH 7.5 to 5.5) resulted in the induction of an acid tolerance response (ATR) increasing survival at low pH (3.5-3.0). The current study was designed to determine whether two fresh isolates, $\mathrm{H7}$ and BM71, and two laboratory strains, Ingbritt and LT11, were capable of a stationary-phase ATR as estimated by a survival test at pH 3.5 for $3 \mathrm{~h}$. All four strains were unable to generate a stationaryphase ATR under control conditions at pH 7.5, with the exception of a burst of survivors in the transition between the exponential and stationary phases when the carbon source (glucose) was depleted. Adaptation at pH 5.5 resulted in the expected pH-dependent exponential-phase ATR, but only the fresh isolates exhibited a stationary-phase ATR at this pH. Glucose starvation of cells in complex medium was shown to enhance acid tolerance for the fresh isolates, but not the laboratory strains. This tolerance was, however, greatly diminished for all strains in a defined medium with a low concentration of amino acids. Growth of strain $\mathrm{H7}$ in complex medium resulted in the formation of at least 56 extracellular proteins, nine of which were degraded in the early stationary phase following the induction of proteolytic activity during the transition period. No proteolytic activity was observed with strain LT11 and only 19 extracellular proteins/peptides were apparent in the medium with only one being degraded in the early stationary phase. Strain $\mathrm{H7}$ was also shown to have two- to fourfold higher levels of intracellular glycogen in the stationary phase than strain LT11. These results suggest that $\mathrm{S}$. mutans $\mathrm{H7}$ possessed the required endogenous metabolism to support amino acid/peptide uptake in the early-stationary phase, which resulted in the formation of basic end products that, in turn, contributed to enhanced intracellular pH homeostasis.
\end{abstract}

Keywords : acidurance, starvation, protein secretion, oral streptococci

\section{INTRODUCTION}

The bacteria in dental plaque are subjected to continual cycles of 'acid shock' created by the rapid accumulation of metabolic acid end products generated during the metabolism of dietary carbohydrate by the acidogenic plaque microflora. Studies using in vivo $\mathrm{pH}$ telemetry have shown reductions in plaque $\mathrm{pH}$ from 7 to below 4 in as little as $3 \mathrm{~min}$ with the $\mathrm{pH}$ returning to neutral values at a much slower rate (Imfeld \& Lutz, 1980;

Abbreviation: ATR, acid tolerance response.
Yamada et al., 1980; Jensen et al., 1982). The frequent and consistent intake of sugar over time will result in the prolonged suppression of plaque $\mathrm{pH}$, a process that can lead to dental caries. Thus the organisms associated with the disease, such as Streptococcus mutans, Lactobacillus species and certain non-mutans streptococci (Bowden, 1991; van Houte et al., 1996), are not only able to generate acid from carbohydrate substrates, but also possess the capacity to tolerate acidic environments for prolonged periods of time.

Previously, we have demonstrated the induction of an acid tolerance response (ATR) by exponential-phase 
cultures of $S$. mutans in response to an acid shock from $\mathrm{pH} 7 \cdot 5$ to 5.5 that resulted in enhanced survival at low $\mathrm{pH}, 3 \cdot 5-3 \cdot 0$ (Svensäter et al., 1997). This 'exponentialphase' ATR required protein synthesis, since survival was abolished in the presence of chloramphenicol. The incubation of cells with ${ }^{14} \mathrm{C}$-labelled amino acids during the acid shock, followed by protein extraction and PAGE analysis, demonstrated the transient upregulation of acid-responsive proteins over a $2 \mathrm{~h}$ period (Hamilton \& Svensäter, 1998). More recently, 2D electrophoresis has demonstrated the up-regulation of 64 proteins within the first $30 \mathrm{~min}$ of a $\mathrm{pH}$ change from $7 \cdot 5$ to $5 \cdot 5$, with 49 proteins down-regulated during the same period (Svensäter et al., 2000). Of the up-regulated proteins, 25 were specific to the acid response, while other proteins were also influenced by alternative stress conditions. These proteins are undoubtedly related to the variety of physiological changes observed with cells of $S$. mutans following a shift in $\mathrm{pH}$ from 7.5 to 5.5 , while growing in continuous culture with a glucose limitation (Hamilton \& Buckley, 1991).

Enteric bacteria possess a variety of acid survival systems with the responses differing depending on the growth medium, the stage of growth and other factors (Foster, 1995; Lin et al., 1995; Castanie-Cornet et al., 1999). The earlier known acid response of Salmonella typhimurium, now known as the "pH-dependent exponential-phase ATR' (Lee et al., 1994), is supplemented by at least two other strategies: a $\mathrm{pH}$-independent general stress resistance dependent on the alternative sigma factor RpoS $\left(\sigma^{\mathrm{S}}\right)$, and an additional $\mathrm{pH}$-dependent stationary-phase ATR. Comparisons between the acid-survival strategies in Sal. typhimurium, Escherichia coli and Shigella flexneri have indicated that all these organisms possessed the RpoS-dependent resistance system, while the latter two organisms possess several 'acid-resistance' systems not present in Sal. typhimurium and requiring components of complex medium, such as glutamate and arginine (Lin et al., 1995). Recent work with E. coli has shown that cells actually possess three overlapping acidresistance systems to protect stationary-phase cells in acid environments (Castanie-Cornet et al., 1999).

Although current evidence indicates that most oral streptococci generate a pH-dependent exponentialphase ATR (Svensäter et al., 1997; Hamilton \& Svensäter, 1998), little information is available on the acid tolerance of oral streptococci during very slow growth or in the stationary phase, conditions frequently encountered by bacteria in dental plaque (Brecx et al., 1983). Unlike enteric bacteria, oral streptococci are relatively inactive metabolically in the stationary phase unless they have synthesized endogenous energy reserves, such as glycogen, in the presence of exogenous carbohydrate. In addition, upon depletion of the energy reserves, the transmembrane $\mathrm{pH}$ gradient will dissipate with the intracellular $\mathrm{pH}$ assuming the same value as the external $\mathrm{pH}$, which in acidic environments will result in cessation of cellular activity (Hamilton, 1990). As a consequence, we were interested in whether $S$. mutans could generate an ATR in the stationary phase and, if so, what factors influenced such a response. For this, we compared the acid tolerance of two freshly isolated and two laboratory strains of $S$. mutans growing in complex medium at $\mathrm{pH} 7.5$ and 5.5 , using survival at $\mathrm{pH} 3.5$ for $3 \mathrm{~h}$ as a measure of acid resistance. Unlike the laboratory strains, the freshly isolated strains were shown to possess a pH-dependent stationary-phase ATR and acid resistance was increased by carbon starvation in complex medium. Using the fresh isolate $S$. mutans $\mathrm{H} 7$ as a model system, it was demonstrated that stationary-phase acid tolerance appears to be related to enhanced protein secretion and degradation in the early-stationary phase.

\section{METHODS}

Bacterial strains and media. The organisms in this study included two established laboratory strains: $S$. mutans LT11, provided by R. R. B. Russell, Newcastle upon Tyne, UK, and $S$. mutans Ingbritt, obtained from J. Sandham, University of Toronto, Canada. The two fresh isolates included $S$. mutans $\mathrm{H} 7$, isolated from an approximal caries lesion at $\mathrm{pH} 5 \cdot 0$, and S. mutans BM71, isolated from human dental plaque and obtained from G. Bowden, University of Manitoba, Canada. The laboratory transfer of the fresh strains used in this study was restricted to the four to five subcultures necessary for isolation and purification of the culture. Growth was carried out anaerobically $\left(9 \% \mathrm{H}_{2}, 5 \% \mathrm{CO}_{2}\right.$ in nitrogen) with both complex and minimal media: the basal complex medium comprised $\left(\mathrm{g} \mathrm{l}^{-1}\right)$ tryptone (10) and yeast extract (5) buffered with $40 \mathrm{mM}$ phosphate/citrate buffer (TYE) supplemented with $20 \mathrm{mM}$ glucose (TYEG), while the defined medium (MADM) was that previously described by Bowden et al. (1976) with the Casamino acid content adjusted to $200 \mathrm{mg} \mathrm{l}^{-1}$. Plate counts of cells surviving an acid challenge at $\mathrm{pH} 3.5$ were carried out with trypticase agar comprising $\left(\mathrm{g}^{-1}\right)$ : trypticase (10), yeast extract (2), sodium carbonate (2), glucose (2), $\mathrm{NaCl}$ (5) and agar (10) with the $\mathrm{pH}$ adjusted to $7 \cdot 2$.

Acid tolerance during growth. To test for $\mathrm{pH}$-dependent and $\mathrm{pH}$-independent stationary-phase ATRs, the acid resistance of cells was tested during normal 'batch' growth. Cells were grown anaerobically in TYEG at $\mathrm{pH} 7.5$ or 5.5 with the culture $\mathrm{pH}$ maintained by the addition of $\mathrm{KOH}$. The $\mathrm{pH}$ varied by less than $\pm 0 \cdot 3$ units throughout the growth period. Periodically, duplicate culture samples were removed and the cells were subjected to an acid challenge at $\mathrm{pH} 3.5$ for $3 \mathrm{~h}$ followed by plating for survivors on trypticase agar. This latter $\mathrm{pH}$ is $0 \cdot 2-0.5$ units above the $\mathrm{pH}$ which kills $100 \%$ of exponentialphase cells grown at $\mathrm{pH} 7 \cdot 5$ (Svensäter et al., 1997). Rapid acidification was achieved by centrifuging $1.0 \mathrm{ml}$ of the culture suspension in a microfuge at $15000 \mathrm{~g}$ for $3 \mathrm{~min}$, washing the cells twice in pre-warmed sterile TYEG buffered at $\mathrm{pH} 3.5$ and resuspending the cells in the same medium prior to incubation at $37^{\circ} \mathrm{C}$. All dilutions were plated in triplicate with the plates incubated at $37^{\circ} \mathrm{C}$ for a minimum of $3 \mathrm{~d}$. The percentage of cell survivors at each time point was calculated by comparing the numbers of cells surviving the pH 3.5 challenge and the number of cells in the original culture sample just prior to acidification. The data presented represent the mean of at least three separate determinations with the standard errors calculated by the Statview program for the Macintosh.

Glucose-depleted 'stationary phase'. To assess the effect of glucose depletion on acid tolerance, exponential-phase cells grown at $\mathrm{pH} 7.5$ in either TYEG or MADM were rapidly washed and resuspended in the same medium at $\mathrm{pH} 7.5$ and 
$5 \cdot 5$ without glucose. Following a $2 \mathrm{~h}$ adaptation period at $37^{\circ} \mathrm{C}$, duplicate cell samples were removed for plate counts on trypticase agar prior to rapid acidification of the culture to $\mathrm{pH} 3.5$ as described above. In order to determine the rate of acid killing, duplicate samples were removed each hour over a $3 \mathrm{~h}$ period and the cultures were diluted and plated for survivors on trypticase agar. As above, the percentage survival was calculated from the cell counts obtained during exposure to $\mathrm{pH} 3.5$ and compared to those of the same samples prior to acidification to $\mathrm{pH} 3 \cdot 5$. Control cells were incubated in the same medium supplemented with $20 \mathrm{mM}$ glucose. The $\mathrm{pH}$ in all experiments varied less than $\pm 0 \cdot 2$ units during any incubation period and the data presented represent the mean of at least three separate determinations.

Intracellular glycogen analysis. The glycogen content of cells was determined during the growth of the test strains in TYE containing $10 \mathrm{mM}$ glucose. Culture samples $(10 \mathrm{ml})$ were removed periodically to a boiling water bath for $10 \mathrm{~min}$ followed by centrifugation at $15000 \mathrm{~g}$ for $15 \mathrm{~min}$. The boiled cells were washed twice in cold distilled water and resuspended at $0.4 \mathrm{mg}$ dry weight $\mathrm{ml}^{-1}$ and then frozen $\left(-70^{\circ} \mathrm{C}\right)$ until analysed for glycogen. Glycogen was assayed by the method of DiPersio et al. (1974).

2D gel electrophoresis. Culture supernatant fractions were filter-sterilized $(0 \cdot 22 \mu \mathrm{m})$ and concentrated 10-fold (UltrafreeMC, 5000 NMWL; Millipore) and the proteins/peptides were separated by $2 \mathrm{D}$ electrophoresis essentially as previously described by Svensäter et al. (2000). The first dimension isoelectric focusing was run on linear $7 \mathrm{~cm}$ immobilized $\mathrm{pH}$ gradient (IPG) strips (Amersham Pharmacia Biotech) in the $\mathrm{pH}$ range 4-7 and the proteins were separated by $150 \mathrm{~V}$ for $1 \mathrm{~h}, 300 \mathrm{~V}$ for $1 \mathrm{~h}, 600 \mathrm{~V}$ for $1 \mathrm{~h}$ and $3500 \mathrm{~V}$ for $13 \mathrm{~h}$. Following separation, the strips were immediately frozen at $-80^{\circ} \mathrm{C}$ until the second dimension, SDS-PAGE, could be carried out with $10 \%$ polyacrylamide gels using the Mini Protean II system (Bio-Rad). The gels were then silver-stained according to the manufacturer (Amersham Pharmacia Biotech) and scanned with a calibrated UMAX transmission scanner. Spot volumes were determined with Biolmage software (version 1.6) on a Sun UltraSparc workstation (Genomic Solutions) and were defined as the sum of the pixel values comprising the protein minus the sum of the background pixel values. A reference gel was chosen and each of the other gels was matched to it selecting anchor proteins on the images and allowing the BioImage software to automatically match the images. Proteins of known molecular mass were used as standards to generate molecular mass values and $\mathrm{pI}$ values were deduced from the linearity of the IPG strips.

Zymography. Proteins in filtered culture supernatants were concentrated (100-fold) by centrifugal filtration (Amicon) and separated on $10 \%$ SDS-PAGE gels containing covalently bound gelatin or $12 \%$ SDS-PAGE gels containing covalently bound casein (Bio-Rad). Electrophoresis was carried out at $100 \mathrm{~V}$ for $2 \mathrm{~h}$ at room temperature. The gels were then incubated at room temperature in $2.5 \%$ Triton X-100 for $30 \mathrm{~min}$ and then placed in a developing buffer $(50 \mathrm{mM}$ Trisbase, $\mathrm{pH} 7 \cdot 5 ; 0.2 \mathrm{M} \mathrm{NaCl} ; 5 \mathrm{mM} \mathrm{CaCl}_{2} ; 0.02 \%$ Brij-35) overnight at $37^{\circ} \mathrm{C}$. The gels were then stained with $0.5 \%$ Coomassie brilliant blue in $40 \%$ methanol $/ 10 \%$ acetic acid for $1 \mathrm{~h}$ and destained with $40 \%$ methanol/10\% acetic acid. Protease activity was detected as a clear zone against a stained background.

Analytical procedures. Protein was determined by the method of Bradford (1976), while glucose was assayed enzymically by the method of Kingsley \& Getchell (1960).

\section{RESULTS}

\section{Stationary phase and acid tolerance}

The acid tolerance of the test strains was assessed during the various phases of batch growth in complex medium (TYEG) at $\mathrm{pH} 7.5$ and 5.5 by determining the numbers of cells capable of surviving an acid challenge at $\mathrm{pH} 3.5$ for $3 \mathrm{~h}$. As expected from previous results (Svensäter $e t$ al., 1997), no survivors were observed with unadapted exponential-phase cells of the laboratory strain $S$. mutans LT11 (Fig. 1a) and the fresh isolate S. mutans H7 (Fig. 2a). However, a small number of survivors were observed during the transition between the exponential and stationary phases when the carbon source was depleted, but this increase was short-lived and did not extend to stationary-phase cells. Conversely, growth of the organisms at $\mathrm{pH} 5.5$ (Figs $1 \mathrm{~b}$ and $2 \mathrm{~b}$ ) resulted in the expected increase in survivors due to the induction of the exponential-phase ATR with $S$. mutans $\mathrm{H} 7$ generating significantly more survivors than strain LT11. Entry into the stationary phase, however, resulted in a major difference between the strains: the number of survivors of LT11 decreased to zero immediately the cells entered the stationary phase (Fig. 1b), while the numbers of

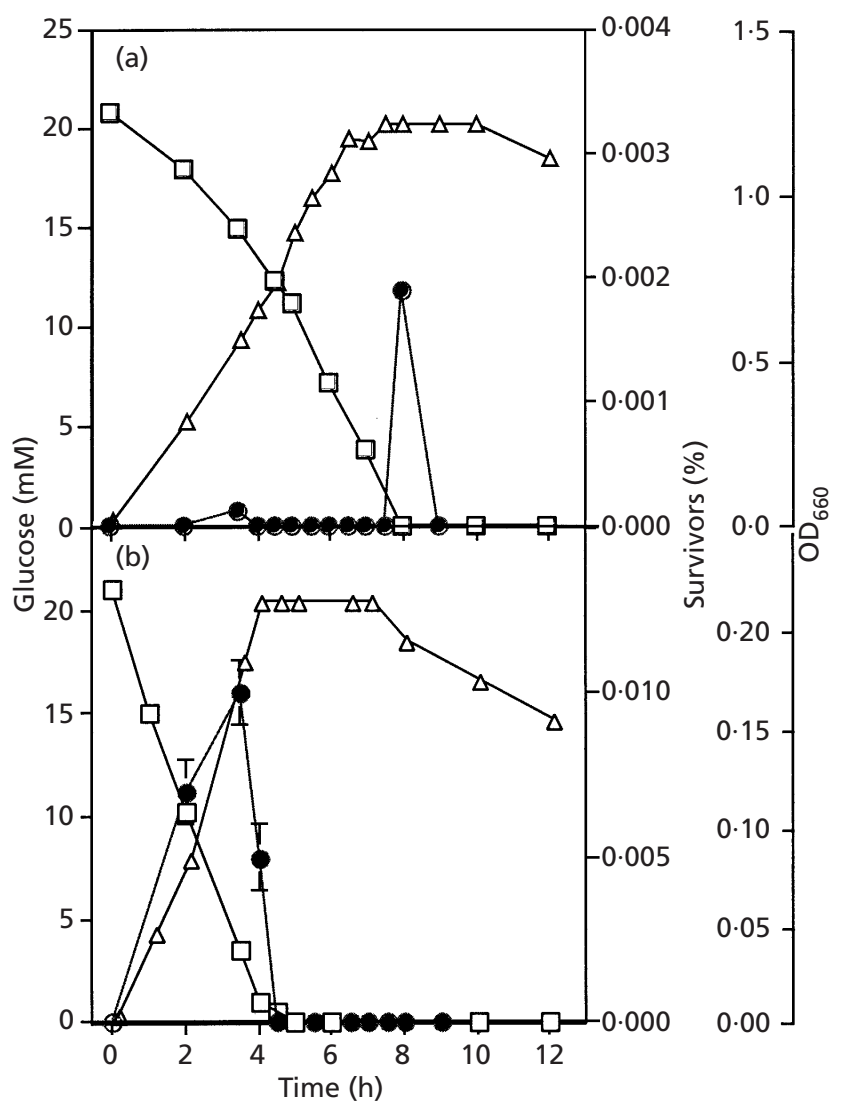

Fig. 1. Batch growth of $S$. mutans LT11 in TYEG at pH 7.5 (a) and $\mathrm{pH} 5.5$ (b). $\triangle$, Growth measured at $\mathrm{OD}_{660} ; 0$, numbers of survivors in culture samples following a $3 \mathrm{~h}$ exposure at $\mathrm{pH} 3.5$ in the same medium; $\square$, glucose concentration in the medium $(\mathrm{mM})$. 

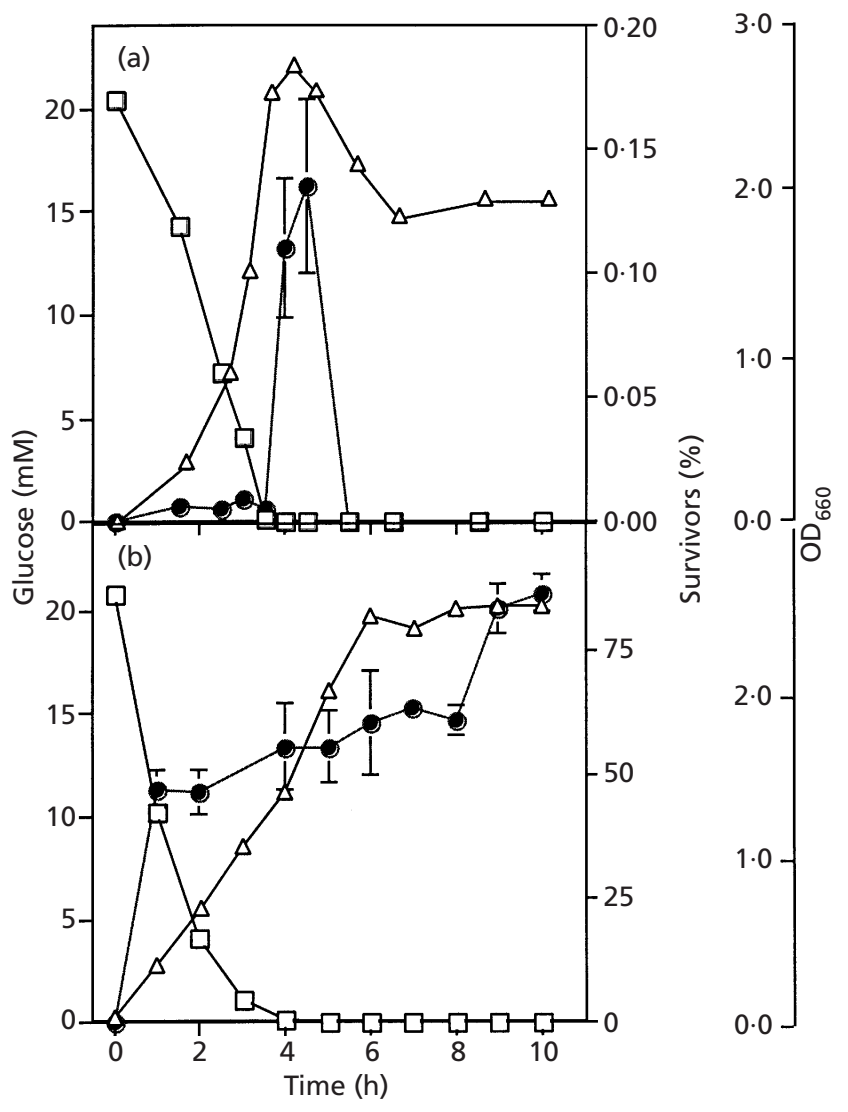

Fig. 2. Batch growth of $S$. mutans $H 7$ in TYEG at $p H 7 \cdot 5$ (a) and $\mathrm{pH} 5.5$ (b). $\triangle$, Growth measured at $\mathrm{OD}_{660} ; 0$, numbers of survivors in culture samples following a $3 \mathrm{~h}$ exposure at $\mathrm{pH} 3.5$ in the same medium; $\square$, glucose concentration in the medium $(\mathrm{mM})$.

strain $\mathrm{H} 7$ increased in cell samples removed during the transition and early-stationary phase of growth (Fig. $2 \mathrm{~b})$. This result indicates the presence of a $\mathrm{pH}$-dependent stationary-phase ATR in the latter organism that is absent in LT11. Similar experiments were carried out with the laboratory strain $S$. mutans Ingbritt and the fresh isolate $S$. mutans BM71, and these confirmed the differences between the laboratory and fresh strains. In summary, the results indicate that while all four strains possessed the $\mathrm{pH}$-dependent exponential-phase ATR, only the fresh strains, $\mathrm{H} 7$ and BM71, possessed the $\mathrm{pH}$ dependent stationary-phase ATR.

\section{Influence of the carbon source}

The abrupt changes in survivors seen in Figs 1 and 2 upon depletion of the glucose suggested a possible link between carbon starvation and the ATR. To examine further the influence of glucose on survival, exponentialphase cells, grown at $\mathrm{pH}$ 7.5 in complex TYEG medium, were rapidly washed and incubated in the same medium at $\mathrm{pH} 7.5$ and 5.5 without glucose (TYE) for $2 \mathrm{~h}$ to simulate entry into 'carbon-starved' stationary phase

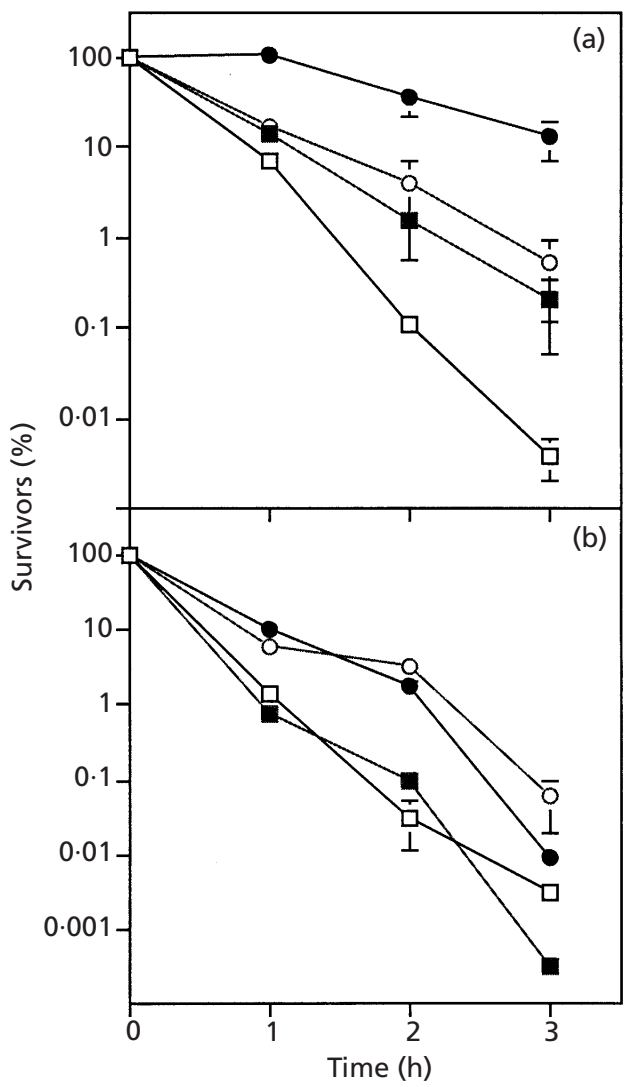

Fig. 3. Effect of glucose starvation on the rate of acid killing of adapted and unadapted cells of S. mutans $\mathrm{H7}$ (a) and S. mutans Ingbritt (b) at $\mathrm{pH} 3 \cdot 5 . \square$, $\mathbf{0}$, Unadapted cells (pH 7.5) with and without glucose, respectively; $\bigcirc, 0$, adapted cells ( $\mathrm{pH} 5.5)$ with and without glucose, respectively. Cells were incubated for $2 \mathrm{~h}$ in TYE at either $\mathrm{pH} 7.5$ or 5.5 with and without glucose before being concentrated, washed and incubated in the same medium at $\mathrm{pH} 3 \cdot 5$, with survivors assessed each hour for $3 \mathrm{~h}$.

before being subjected to the acid challenge at $\mathrm{pH} 3 \cdot 5$. Control cells were incubated under the same conditions in medium with glucose (TYEG). As seen with $S$. mutans $\mathrm{H} 7$ (Fig. 3a), incubation at $\mathrm{pH} 5.5$ in TYEG resulted in 2- to 135-fold higher number of survivors over the $3 \mathrm{~h}$ acid challenge when compared to TYEG cells at $\mathrm{pH} 7 \cdot 5$ demonstrating induction of the ATR. Incubation at pH 5.5 without glucose, however, generated 6- to 25fold higher numbers of survivors than the $\mathrm{pH} 5.5$ cells in TYE with glucose. In addition, the incubation of $\mathrm{pH} 7 \cdot 5$ unadapted cells in glucose-free TYE resulted in 2- to 50fold higher numbers of survivors than the same cells incubated with glucose. Thus glucose starvation of $S$. mutans $\mathrm{H} 7$ enhanced acid resistance in both adapted and unadapted cells, implicating glucose starvation in both $\mathrm{pH}$-dependent and $\mathrm{pH}$-independent stationaryphase acid tolerance. Similar results were obtained with S. mutans BM71 (data not shown). When these experiments were repeated with the laboratory strain $S$. mutans Ingbritt (Fig. 3b), the results indicated that the organism was more acid sensitive than strain $\mathrm{H} 7$ with no 


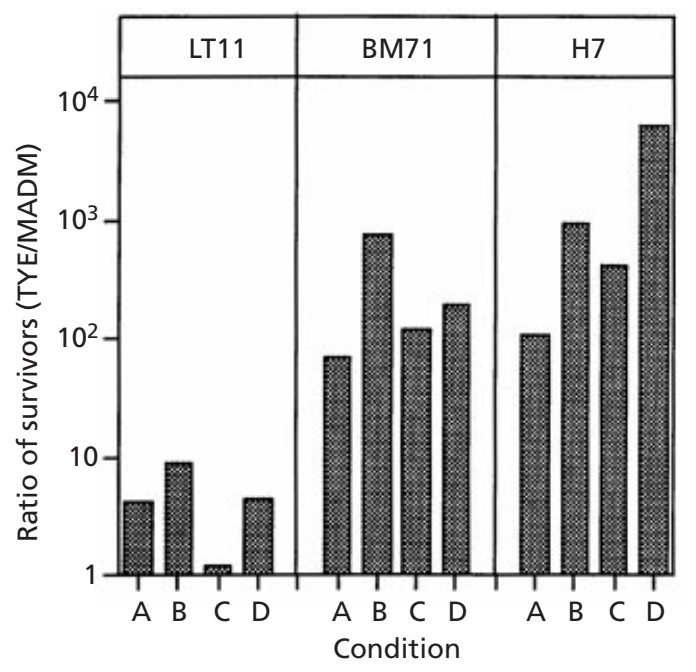

Fig. 4. Ratio of survivors of $S$. mutans LT11, S. mutans BM71 and $S$. mutans $\mathrm{H} 7$ in TYE versus MADM medium at $\mathrm{pH} 3.5$ in the presence and absence of glucose. A, Unadapted cells with glucose; B, unadapted cells without glucose; C, adapted cells with glucose; $D$, adapted cells without glucose. Cells were incubated for $2 \mathrm{~h}$ in TYE with and without glucose before being concentrated, washed and incubated in the same medium at $\mathrm{pH} 3.5$ for $2 \mathrm{~h}$.

sustained effect of glucose starvation on acid tolerance, a result also seen with $S$. mutans LT11 (data not shown).

\section{Influence of the amino acids/proteins}

When the experiment in Fig. 3(a) was repeated with $S$. mutans $\mathrm{H} 7$ grown in a defined medium (MADM) supplemented with a low level of amino acids $(0 \cdot 02 \%)$, acid resistance was significantly diminished with little effect of the presence or absence of glucose. That a component in, or derived from, the complex medium enhances acid resistance can be seen by comparing the numbers of survivors in TYE to those in MADM (Fig. 4). In this comparison, the numbers of $\mathrm{H} 7$ survivors in TYE were two to four orders of magnitude greater than those obtained with cells in MADM, with similar results (e.g. two to three orders of magnitude) obtained with S. mutans BM71. A similar comparison with the laboratory strain $S$. mutans LT11 indicated that this organism was only marginally influenced by the nature of the growth medium with increases ranging from only two- to ninefold, a finding similar to that seen with S. mutans Ingbritt (data not shown).

\section{Protein degradation}

The increased acid resistance by cells of $S$. mutans $\mathrm{H} 7$ and BM71 in complex medium strongly suggested that the metabolism of the proteins and/or peptides present in the TYE medium, but not in the MADM medium, might have contributed to the increased acid tolerance of the fresh isolates by the generation of basic cellular (a)

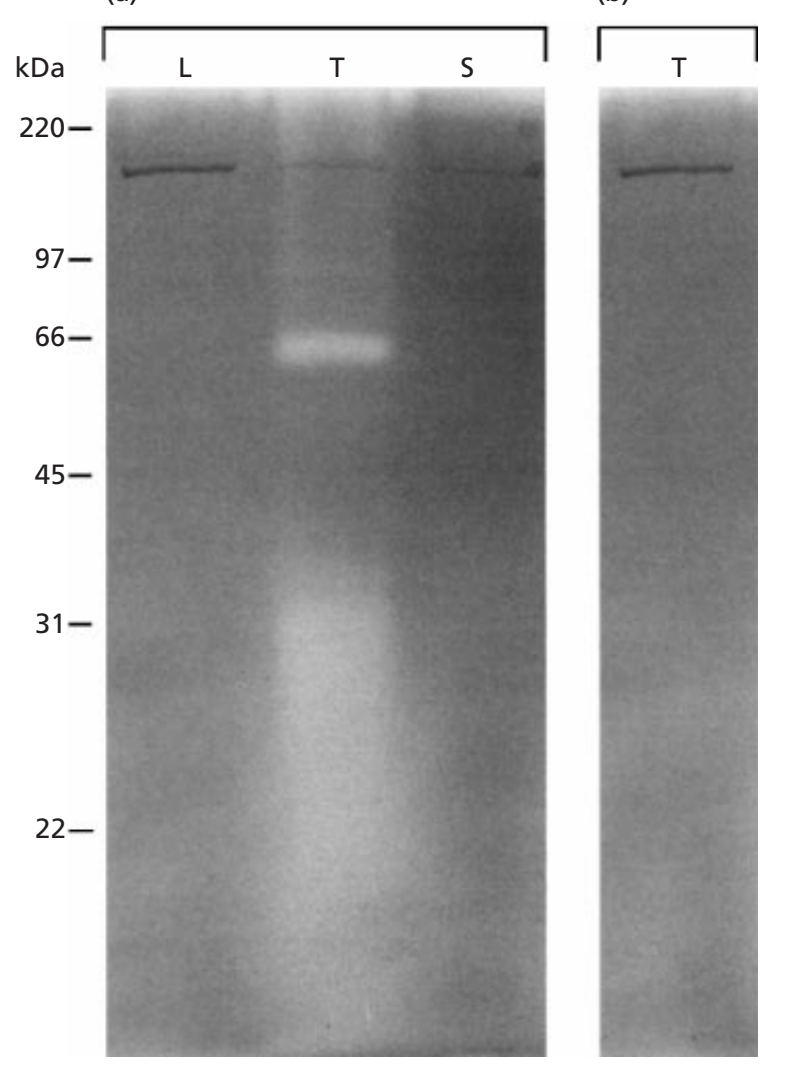

Fig. 5. Gelatin zymograms of cell-free culture supernatant fractions isolated during the growth of S. mutans $\mathrm{H7}$ (a) and S. mutans LT11 (b) in TYEG. L, Mid-exponential phase; $\mathrm{T}$, transition between exponential and stationary phases; $S$, stationary phase.

metabolic end products. This possibility was enhanced by the observation that cells of strain $\mathrm{H} 7$ induced protease activity in the transition phase prior to entry into the stationary phase, activity that was not observed in strain LT11 (Fig. 5). The H7 protease activity, which was transitory, being absent in exponential- or stationary-phase cells, was linked to at least two proteolytic zones with estimated molecular masses of $55 \mathrm{kDa}$ and $25-32 \mathrm{kDa}$. Proteolytic activity was observed with gelatin, but not with casein, as the substrate.

This observation led to an examination of the proteins and peptides present in the medium during growth of S. mutans H7 and strain LT11 in TYE medium with $20 \mathrm{mM}$ glucose. For this experiment, the cells were removed by centrifugation and the cell-free culture supernatant was sterilized by filtration, concentrated 10fold by centrifugal filtration, and then subjected to $2 \mathrm{D}$ electrophoresis. The 2D gel analysis revealed that strain H7 generated 56 extracellular proteins in midexponential phase compared to 19 proteins by strain LT11 with proteins ranging in size from 5 to $200 \mathrm{kDa}$. Comparative analysis of the proteins in a selected gel 
(a)

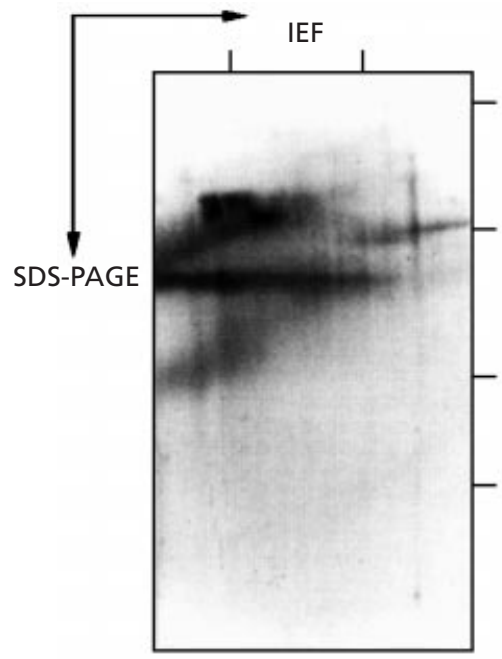

(b)
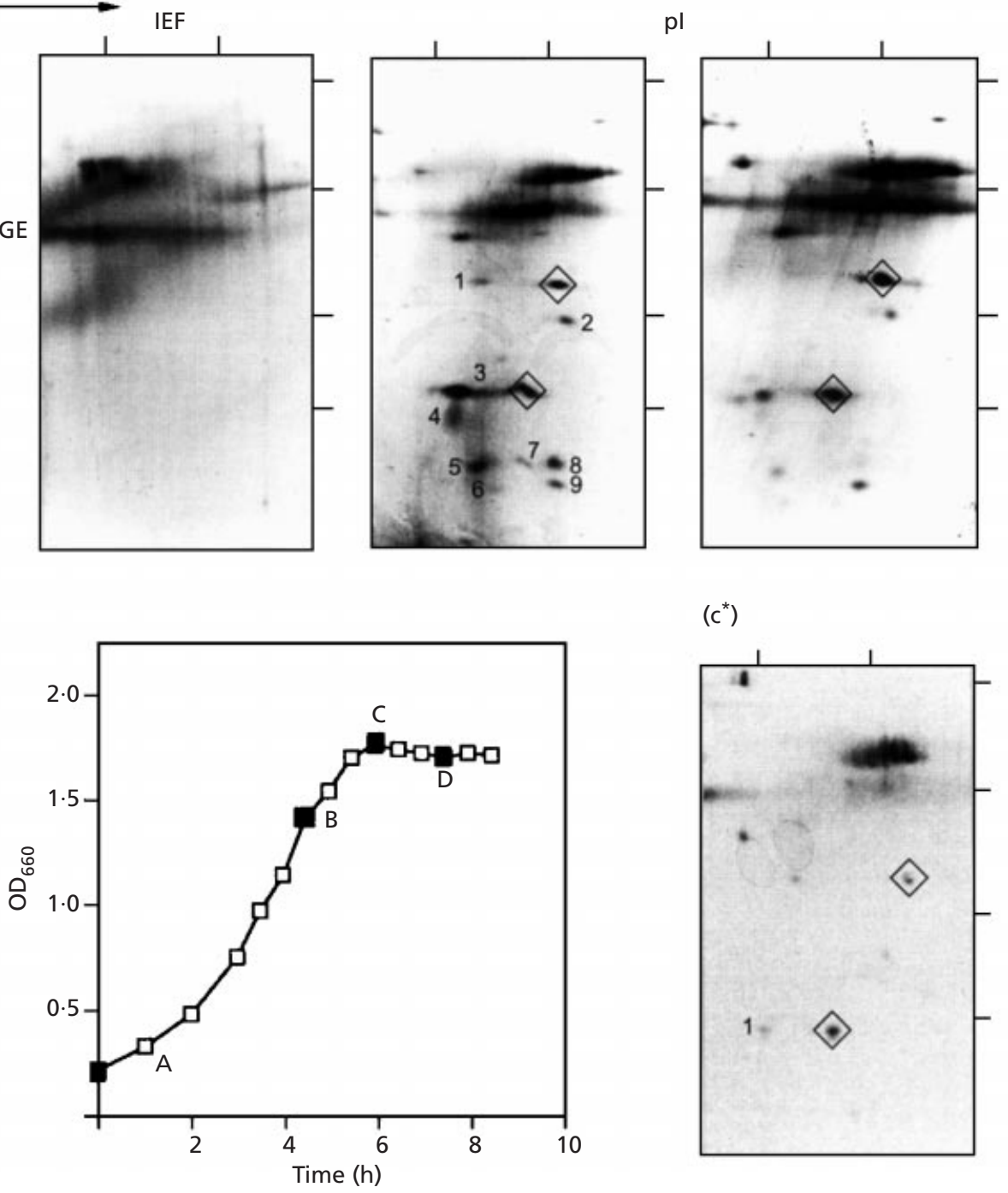

$\left(c^{*}\right)$

(c)

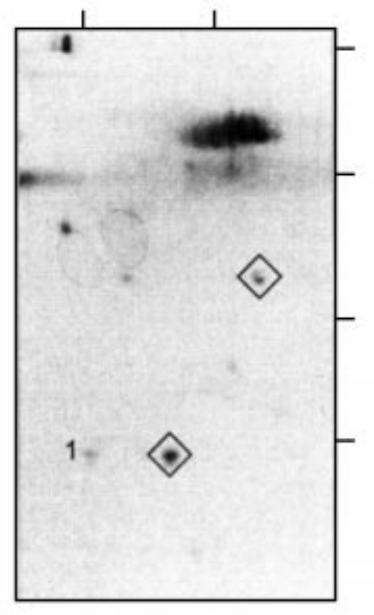

(d)

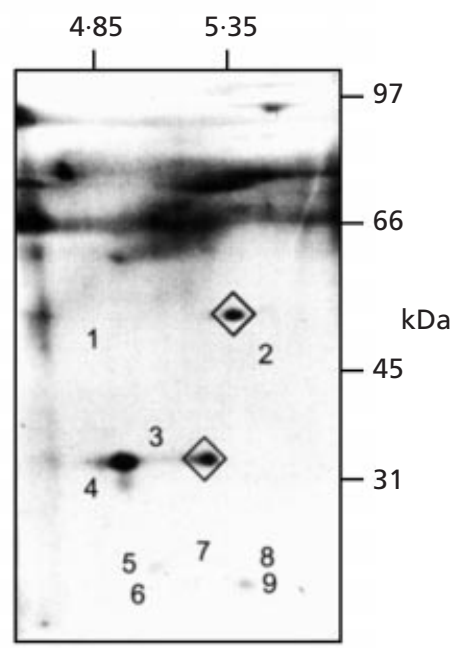

$\left(d^{*}\right)$

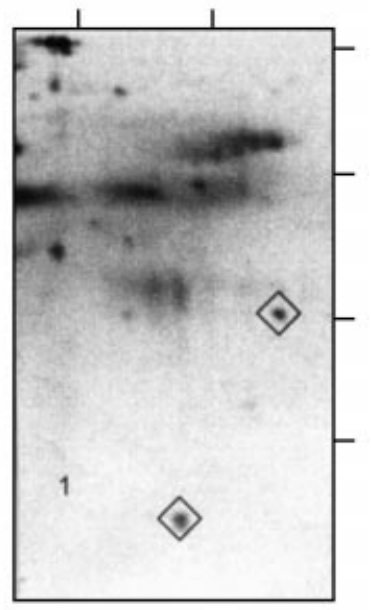

Fig. 6. Silver-stained 2D gels of cell-free culture supernatant fractions isolated during the growth of $S$. mutans $\mathrm{H} 7$ (a-d) and $S$. mutans LT11 $\left(a, c^{*}, d^{*}\right)$ in TYEG. The gel in (a) is the original uninoculated medium, while (b)-(d) conform to the samples indicated on the growth curve.

Table 1. Glycogen present in cells of Streptococcus mutans strains H7 and LT11 during growth on tryptone-yeast extract medium at $\mathrm{pH} 7 \cdot 5$ with $10 \mathrm{mM}$ glucose as the carbon source

\begin{tabular}{|lccc|}
\hline Growth phase & S. mutans $\mathrm{H}^{*}$ & S. mutans LT11* & Ratio H7/LT11 \\
\hline Late exponential & $41 \cdot 2 \pm 14 \cdot 4$ & $10 \cdot 3 \pm 10 \cdot 8$ & $4 \cdot 0$ \\
Transition & $43 \cdot 8 \pm 22 \cdot 2$ & $21 \cdot 3 \pm 1 \cdot 9$ & $2 \cdot 1$ \\
Early stationary & $29 \cdot 1 \pm 14 \cdot 9$ & $11 \cdot 0 \pm 0 \cdot 6$ & $2 \cdot 7$ \\
\hline
\end{tabular}

*Values represent mg glycogen (g dry wt cells $)^{-1} \pm \mathrm{SE}$.

area (pI range 4.5-6) showed that mid-exponentialphase cells of strain $\mathrm{H} 7$ (Fig. 6b) generated at least nine proteins that were either completely (spots 1, 2, 3, 6, 7 and 8) or partially (spots 4, 5 and 9) degraded by the time the cells had reached the stationary phase (Fig. 6d). S. mutans LT11, on the other hand, generated only one 
protein (spot 1) that was degraded on entry to the stationary phase (Fig. $6 \mathrm{c}^{*}$ vs $\mathrm{d}^{*}$ ).

\section{Energy status of early-stationary-phase cells}

Enzymic analysis of the cell-free supernatant samples in the experiment depicted in Fig. 6 indicated that the glucose was completely depleted upon entry into the transition period. This raised the question as to the source of energy available to cells for the maintenance of $\mathrm{pH}$ homeostasis, as well as for the reactions associated with protein degradation and amino acid/peptide transport in the transition and early-stationary phases of growth. With glucose as the exogenous energy source, oral streptococci have a variable capacity to synthesize intracellular glycogen and this was demonstrated in experiments comparing the glycogen synthetic activity of S. mutans H7 and strain LT11 during growth in TYE with $10 \mathrm{mM}$ glucose. As seen in Table 1, strain H7 possessed two- to fourfold more glycogen than LT11 upon entry into the transition and stationary phases.

\section{DISCUSSION}

The results of the current research indicate that fresh isolates possess additional properties for protection against acid stress not observed with the strains transferred in laboratory medium for prolonged periods of time. None of the $S$. mutans strains in this study exhibited a sustained ATR during batch growth at $\mathrm{pH} 7.5$ in either the exponential or stationary phases, although a small increase in survivors was seen in the transition between these two phases that was not sustained in the stationary phase (Figs 1 and 2). Growth at $\mathrm{pH} 5.5$ for $2 \mathrm{~h}$ did, however, induce an ATR in exponential-phase cells of all strains, confirming earlier results (Svensäter et al., 1997), but only the fresh isolates, strains $\mathrm{H} 7$ and BM71, were able to sustain a $\mathrm{pH}-$ dependent stationary-phase ATR. While not often acknowledged, fresh isolates of oral bacteria possess different properties to those transferred for long periods of time in complex laboratory medium. For example, $S$. mutans and other oral streptococci have been shown to undergo significant alterations in enzyme composition and activity in as little as 225 daily transfers in the laboratory (Cvitkovitch \& Hamilton, 1994), not an unreasonable observation when one compares the nutrients available in dental plaque with that of laboratory medium comprised of preformed essential nutrients.

One feature not readily assessed in the growth experiments was the nature of the short transitory increase in survivors as the cells entered the stationary phase (Figs 1 and 2) at a point that coincided with the depletion of glucose. That the effect was due to the depletion of glucose was seen in the 'artificial stationary-phase' experiment which showed with strain $\mathrm{H} 7$ (Fig. 3a) that, while adapted cells were inherently more acid resistant than unadapted cells, the acid tolerance of unadapted and adapted cells was enhanced by the absence of glucose during the acid challenge at $\mathrm{pH} 3.5$ over the $3 \mathrm{~h}$ period. No such differential effect was seen with the laboratory strain S. mutans Ingbritt (Fig. 3b) and strain LT11. Earlier results with $S$. mutans H7 (Svensäter et al., 2000) have demonstrated cross-protection of cells to acid killing by prior exposure of cells to starvation conditions. Starvation, induced by exposure of cells to fivefold diluted basal medium, was most protective when the glucose concentration was diluted from 20 to $4 \mathrm{mM}$, although an enhanced effect over cells adapted in full-strength medium was seen when the diluted medium was devoid of glucose.

Carbohydrate-starved cells of Lactobacillus lactis IL1403 exhibit enhanced resistance to acid, heat, ethanol, osmotic and oxidative stress with this crossprotection occurring progressively with the onset of stationary phase (Hartke et al., 1994). Unlike the development of the ATR in exponential-phase cells of $L$. lactis (Rallu et al., 1996), the stationary-phase response was independent of protein synthesis since it was not abolished, but enhanced, by chloramphenicol or rifamycin. The use of transposon mutagenesis with L. lactis MG1363 has suggested a link between acid tolerance and the stringent response since a number of acidresistant mutants had defects in the biosynthetic pathway for the stringent response factor (p)ppGpp (Rallu et al., 1996). Since (p)ppGpp is a key pleiotropic regulator of gene expression and survival in stationary phase (Nyström, 1993), it is conceivable that the stringent response may also be a factor in the regulation of stress in $S$. mutans and other oral streptococci.

The enhanced acid resistance of $S$. mutans $\mathrm{H} 7$ and BM71 in complex medium (TYE) compared to the low amino acid defined medium (MADM) clearly differentiates these strains from $S$. mutans LT11 (Fig. 4). One assumes that differences in the metabolism of proteins, peptides and amino acids by the former organisms are central to this enhanced resistance. The appearance of proteolytic activity with cells of strain $\mathrm{H} 7$ during the transition from exponential to stationary phase (Fig. 5), and the evidence of protein/peptide generation in the culture medium during the exponential phase with subsequent utilization during early-stationary phase (Fig. 6), support this contention. The appearance of a $55 \mathrm{kDa}$ protease in S. mutans $\mathrm{H} 7$, using gelatin as a substrate, confirms an earlier report of such activity by Harrington \& Russell (1994). As to the extracellular proteins/peptides, preliminary experiments indicate that a majority of the proteins in the culture medium seen in Fig. 6 are secreted by $S$. mutans $\mathrm{H} 7$ into the medium mainly during the mid-exponential phase (O. Björnsson \& G. Svensäter, unpublished results). On-going mass spectrometric analysis, using peptide mass fingerprints for protein identification, indicates that the $60 \mathrm{kDa}$ chaperonin DnaK and the glycolytic enzyme enolase are secreted in a manner similar to that recently reported for Streptococcus pyogenes (Chaussee et al., 2001). Extracellular proteins are known to be important virulence factors and while information is emerging as to the regulation of their expression, less is known about their fate and 
whether such proteins can be utilized to enhance acid tolerance.

Work with E. coli and Shigella flexneri has identified 'acid-resistance' systems protecting cells to $\mathrm{pH} 2.5$ and requiring glutamate or arginine during the low $\mathrm{pH}$ challenge with the arginine-acid survival system in $E$. coli involving arginine decarboxylase (Lin et al., 1995). More recently, a glutamate decarboxylase alkalinization cycle was identified in E. coli to protect cells from cytoplasmic acidification (Hersh et al., 1996), refining the early observations of Gale \& Epps (1942). While there is relatively little specific information on the role of amino acids and peptides in acid resistance of $S$. mutans, oral bacteria are known to utilize salivary proteins for growth (Cowman et al., 1979; De Jong et al., 1984) and the uptake of arginine-containing peptides by mixed oral bacteria utilizing glucose has been shown to stimulate $\mathrm{pH}$ increases over that observed with glucose alone (Kleinberg et al., 1976). As the cells enter the stationary phase and the exogenous glucose becomes depleted, an energy source is important for transport processes, consequently the utilization of endogenous carbon reserves, such as glycogen, becomes crucial to cell physiology. This energy source, the principal endogenous energy source for S. mutans (Hamilton, 1976), is also essential for the maintenance of $\mathrm{pH}$ homeostasis by the extrusion of proton via the $\mathrm{H}^{+} /$ATPase (Hamilton \& Buckley, 1991). Thus the increased accumulation of glycogen by $\mathrm{S}$. mutans $\mathrm{H} 7$ compared to strain LT11 (Table 1) would give the former organism a selective energy advantage as the cells entered the stationary phase of growth.

Clearly the current results, coupled with those on the multiple stress response of $S$. mutans $\mathrm{H} 7$ (Svensäter et al., 2000), indicate a strong regulatory link between the acid stress and carbon/nitrogen starvation responses in the organism. In comparing the multiple stress response in S. mutans $\mathrm{H} 7$, it could be shown that the fivefold dilution of a defined medium resulted in the upregulation of 58 proteins, 11 of which were specific to starvation; 20 additional proteins exhibited diminished synthesis. Acid shock from $\mathrm{pH} 7 \cdot 5$ to $5 \cdot 5$, on the other hand, resulted in the up-regulation of 64 proteins and the down-regulation of 49 proteins with 25 specific to the acid response. Of particular interest was the fact that 25 of those proteins that showed enhanced synthesis were common between the acid and starvation responses, and a number of these were associated with enzymes of the glycolytic pathway (unpublished results). Starvation-induced stress resistance is a common feature of both Gram-positive and Gram-negative bacteria with significantly more known about the response in enteric bacteria (Matin, 1991). The $\mathrm{pH}$-independent general stress resistance in Gram-negative bacteria, such as Sal. typhimurium and E. coli, requires the growth-phasedependent transcriptional factor $\sigma^{\mathrm{s}}$, the product of the rpoS gene (Hersh et al., 1996; Lin et al., 1995). While $\sigma^{\text {s }}$ has not been found in Gram-positive bacteria, Bacillus subtilis is known to possess a regulon controlled by the alternative sigma factor $\sigma^{\mathrm{B}}$, regulating 60 general stress proteins activated by various stresses and on entry into the stationary phase (Hecker et al., 1996; Bernhardt et al., 1997).

\section{ACKNOWLEDGEMENTS}

We would like to thank Ulla-Britt Larsson (Malmö) and Elke Greif (Winnipeg) for their excellent technical assistance. This study was supported by grants to G.S. from the Medical Research Council of Sweden (K97-24X-12266-01) and the KK Foundation of Sweden, and to I.R.H. from the Medical Research Council of Canada (MT-3546).

\section{REFERENCES}

Bernhardt, J., Völker, U., Völker, A., Antelmann, H., Schmid, R., Mach, H. \& Hecker, M. (1997). Specific and general stress proteins in Bacillus subtilis - a two-dimensional electrophoretic study. Microbiology 143, 999-1017.

Bowden, G. H. W. (1991). Which bacteria are cariogenic in humans? In Dental Caries, vol. 1, Markers of High and Low Risk Groups and Individuals, pp. 266-286. Edited by N. M. Johnson. Cambridge: Cambridge University Press.

Bowden, G. H. W., Hardie, J. M. \& Fillery, E. D. (1976). Antigens from Actinomyces species and their value in identification. J Dent Res 55, A192-204.

Bradford, M. M. (1976). A rapid and sensitive method for the quantitation of microgram quantities of protein utilizing the principle of protein-dye binding. Anal Biochem 72, 248-254.

Brecx, M., Theilade, J. \& Attström, R. (1983). An ultra structural quantitative study of the significance of microbial multiplication during early plaque growth. J Periodontal Res 18, 177-186.

Castanie-Cornet, M.-P., Penfound, T. A., Smith, D., Elliott, J. F. \& Foster, J. (1999). Control of acid resistance in Escherichia coli. J Bacteriol 181, 3525-3535.

Chaussee, M. S., Watson, R. O., Smoot, J. C. \& Musser, J. M. (2001). Identification of Rgg-regulated exoproteins of Streptococcus pyogenes. Infect Immun 69, 822-831.

Cowman, R. A., Schaefer, S. J. \& Fitzgerald, R. J. (1979). Specificity of utilization of human salivary proteins for growth by oral streptococci. Caries Res 13, 181-189.

Cvitkovitch, D. G. \& Hamilton, I. R. (1994). Biochemical change exhibited by oral streptococci resulting from laboratory subculturing. Oral Microbiol Immunol 9, 209-217.

De Jong, M. H., van der Hoeven, J. S., van Os, J. H. \& Olijve, J. H. (1984). Growth of oral Streptococcus species and Actinomyces viscosus in human saliva. Appl Environ Microbiol 47, 901-904.

DiPersio, J. R., Mattingly, S. J., Higgins, M. L. \& Shockman, G. D. (1974). Measurement of intracellular iodophilic polysaccharide in two cariogenic strains of Streptococcus mutans by cytochemical and chemical methods. Infect Immun 10, 597-604.

Foster, J. W. (1995). Low $\mathrm{pH}$ adaptation and the acid tolerance response in Salmonella typhimurium. Crit Rev Microbiol 21, 215-237.

Gale, E. F. \& Epps, H. M. R. (1942). The effect of pH of the medium during growth on the enzymic activities of bacteria (Escherichia coli and Micrococcus lysodiekticus) and the biological significance of the changes produced. Biochem J 36, 600-619.

Hamilton, I. R. (1976). Intracellular polysaccharide synthesis by cariogenic organisms. In Microbial Aspects of Dental Caries, vol. III, pp. 683-701. Edited by H. M. Stiles, W. J. Loesche \& T. C. O’Brien. Special Supplement Microbiology Abstracts. Washington, DC. 
Hamilton, I. R. (1990). Maintenance of proton motive force by Streptococcus mutans and Streptococcus sobrinus during growth in continuous culture. Oral Microbiol Immunol 5, 280-287.

Hamilton, I. R. \& Buckley, N. D. (1991). Adaptation by Streptococcus mutans to acid tolerance. Oral Microbiol Immunol 6, 65-71.

Hamilton, I. R. \& Svensäter, G. (1998). Acid-regulated proteins induced by Streptococcus mutans and other oral bacteria during acid shock. Oral Microbiol Immunol 13, 292-300.

Harrington, D. J. \& Russell, R. R. B. (1994). Identification and characterization of two extracellular proteases of Streptococcus mutans. FEMS Microbiol Lett 121, 237-242.

Hartke, A., Bouche, S., Gansel, X., Boutibonnes, P. \& Auffray, Y. (1994). Starvation-induced stress resistance in Lactobacillus lactis subsp. lactis IL1403. Appl Environ Microbiol 60, 3474-3478.

Hecker, M., Schumann, W. \& Völker, U. (1996). Heat-shock and general stress response in Bacillus subtilis. Mol Microbiol 19, 417-428.

Hersh, B. M., Farooq, F. T., Barstad, D. N., Blankenhorn, D. L. \& Slonczewski, J. L. (1996). A glutamate-dependent acid resistance gene in Escherichia coli. J Bacteriol 178, 3978-3981.

van Houte, J., Lopman, J. \& Kent, R. (1996). The final pH of bacteria comprising the predominant flora of sound and carious human root and enamel surfaces. J Dent Res 75, 1008-1014.

Imfeld, T. \& Lutz, F. (1980). Intraplaque acid formation assessed in vivo in children and young adults. Pediatr Dent 2, 87-93.

Jensen, M. E., Polansky, P. J. \& Schachtele, C. F. (1982). Plaque sampling and telemetry for monitoring acid production on human buccal tooth surfaces. Arch Oral Biol 27, 21-31.

Kingsley, G. R. \& Getchell, G. (1960). Direct ultra micro glucose oxidase method for the determination of glucose in biological fluids. Clin Chem 6, 466-475.
Kleinberg, I., Kanapka, J. A. \& Craw, D. (1976). Effect of saliva and salivary factors on the metabolism of the mixed oral flora. In Microbial Aspects of Dental Caries, vol. III, pp. 433-446. Edited by H. M. Stiles, W. J. Loesche \& T. C. O’Brien. Special Supplement Microbiology Abstracts. Washington, DC.

Lee, I. S., Slonczewski, J. L. \& Foster, J. W. (1994). A low-pHinducible, stationary phase acid tolerance response in Salmonella typhimurium. J Bacteriol 176, 1422-1426.

Lin, J., Lee, I. S., Frey, J., Slonczewski, J. L. \& Foster, J. W. (1995). Comparative analysis of extreme acid survival in Salmonella typhimurium, Shigella flexneri and Escherichia coli. J Bacteriol 177, 4097-4104.

Matin, A. (1991). The molecular basis of carbon-starvationinduced general resistance in Escherichia coli. Mol Microbiol 5, 3-10.

Nyström, T. (1993). Global systems approach to the physiology of the starved cell. In Starvation in Bacteria, pp. 129-150. Edited by S. Kjelleberg. New York: Plenum.

Rallu, F., Gruss, A. \& Maquin, E. (1996). Lactobacillus lactis and stress. Antonie Leeuwenhoek 70, 243-251.

Svensäter, G., Larsson, U.-B., Greif, E. C. G., Cvitkovitch, D. G. \& Hamilton, I. R. (1997). Acid tolerance response and survival by oral bacteria. Oral Microbiol Immunol 12, 266-273.

Svensäter, G., Sjögreen, B. \& Hamilton, I. R. (2000). Multiple stress responses in Streptococcus mutans and the induction of general and stress-specific proteins. Microbiology 146, 107-117.

Yamada, T., Igarashi, K. \& Mitsutomi, M. (1980). Evaluation of cariogenicity of glycosylsucrose by a new method of measuring pH under human dental plaque in situ. J Dent Res 59, 2157-2162.

Received 2 April 2001; revised 5 June 2001; accepted 15 June 2001 